\title{
The Impact of the El Niño Southern Oscillation on the Number of Visitors to Natural Attractions: The Moderating Effect of Disposable Personal Income, per Capita GDP and Population
}

\author{
Li Xiong ${ }^{1}$, Ke Gong ${ }^{1, *}$, Qingyun Tang ${ }^{1}$, Yuanxiang Dong ${ }^{2}$ and Wei $\mathrm{Xu}^{3}$ \\ 1 School of Economics and Management, Chongqing Jiaotong University, Chongqing 400074, China; \\ xiongli1430602027@163.com (L.X.); e.mmg@163.com (Q.T.) \\ 2 School of Management Science and Engineering, Shanxi University of Finance and Economics, \\ Taiyuan 030006, China; dongyx@sxufe.edu.cn \\ 3 School of Business, Jiangnan University, Wuxi 214122, China; Xuwei@jiangnan.edu.cn \\ * Correspondence: gks_cn@163.com
}

\section{check for} updates

Citation: Xiong, L.; Gong, K.; Tang, Q.; Dong, Y.; Xu, W. The Impact of the El Niño Southern Oscillation on the Number of Visitors to Natural Attractions: The Moderating Effect of Disposable Personal Income, per Capita GDP and Population. Atmosphere 2021, 12, 1189. https:// doi.org/10.3390/atmos12091189

Academic Editor:

Andreas Matzarakis

Received: 19 August 2021

Accepted: 12 September 2021

Published: 15 September 2021

Publisher's Note: MDPI stays neutral with regard to jurisdictional claims in published maps and institutional affiliations.

Copyright: (c) 2021 by the authors. Licensee MDPI, Basel, Switzerland. This article is an open access article distributed under the terms and conditions of the Creative Commons Attribution (CC BY) license (https:/ / creativecommons.org/licenses/by/ $4.0 /)$.

\begin{abstract}
Analyzing the impact of El Nilo Southern Oscillation (ENSO) on the number of tourists is essential in realizing the sustainable development of natural scenic spots. From the current research results, research on the effects of ENSO on tourism focuses on the impact of the formation of the natural environment. However, there is a lack of ENSO-related research on the number of people arriving at natural attractions. This paper considers the adjustment effects of personal disposable income, per capita GDP, and population size and constructs a new framework of ENSO's influence on tourism. This paper builds a system GMM (Gaussian Mixture Model) and analyzes the impact of ENSO on tourist flow by using Google Trend data (big data technology) to obtain annual passenger flow data of 48 natural scenic spots in the United States (mainly national parks and national forests). The empirical results show that the increase in ENSO has led to a significant decrease in visitors to natural attractions in the United States. Moreover, the increase in personal disposable income, per capita GDP, and population size can weaken the relationship between ENSO and the number of tourists. This research expands and enriches the theoretical perspective of ENSO and outdoor tourism.
\end{abstract}

Keywords: climate change; ENSO index; disposable personal income; population; per capita GDP

\section{Introduction}

The tourism industry is exceptionally dependent on climatic conditions [1]. Therefore, climate change can influence tourists' participation in various tourist destination activities through promotion and suppression [2]. Climate change has many manifestations, such as the North Atlantic Oscillation (NAO), Pacific Interdecadal Oscillation (PDO), North Atlantic Interdecadal Oscillation (AMO), El Nino-Southern Oscillation (ENSO), etc., among which ENSO is the most important mode of interannual changes in global climate. In addition, it is a sea-atmosphere coupling phenomenon that changes the weather by influencing temperature and rainfall patterns [3-5].

ENSO will also have an impact on the tourism industry [6]. The specific impact models are as follows: (1) Pulling factors: When the weather conditions related to ENSO show suitable temperature and good rainfall patterns, it can make the desired destination have pleasant weather conditions, and thus to an increase in the number of visitors to attractions. (2) Driving factors: When the weather conditions related to ENSO show excessively high (low) temperature and extreme rainfall patterns, it may cause tourists to change their travel decisions. This can be seen that when a tourist who prefers a suitable climate type has travel needs, the overall weather performance of the scenic spot will have driving or pulling effect. 
The primary purpose of this paper is to study the impact of ENSO on the number of people arriving at natural attractions, taking into account per capita GDP, per capita disposable income, and population adjustment. Academia generally believes that ENSO has a negative impact on the tourism industry of natural attractions. For example, the enhancement of ENSO in the Central Pacific affects the shape of the headland (Bay Beach), and ENSO in different regions has different coastal erosion potential [7]. Under the influence of El Nino, the sea level at the beaches of Southern California Bay has rised faster, which makes beach retention face major challenges [8]. However, the research does not intuitively reflect the impact of ENSO on the tourism industry of natural attractions and the quantitative indicator-the number of tourists who can arrive. As far as we know, no studies have provided direct evidence to prove that ENSO has a negative impact on the number of visitors to natural attractions. This paper aims to fill this research gap.

ENSO is a climate factor that accumulates all year round. Therefore, before arriving at a natural scenic spot, tourists will carefully consider the comprehensive adaptability of temperature, rainfall, and other weather factors caused by ENSO. Furthermore, as natural scenic spots are the most critical objects in tourism activities, the impact of long-term ENSO phenomena and events on the natural scenic spots should be considered. Moreover, a series of feasible measures should be formulated to improve the expressive power of natural scenic spots under long-term ENSO changes. This is of great significance in the strategy of sustainable development of natural attractions.

Tourism researchers usually incorporate economic factors and social demographic factors into tourism demand framework models. Their research describes economic or social demographic factors as the key determinants of tourism demand [9-11]. There is a direct linear relationship between per capita GDP, personal disposable income, population and other factors, and tourism demand from the previous research literature. In other words, regions with better economic development (high personal income or larger population) are more capable of removing barriers on tourism activities. However, faced with the frequent occurrence of ENSO phenomena and incidents, can the per capita GDP and personal disposable income help them to escape from the effects of a bad climate? Can the host population increase the demand for tourism or the number of arrivals? The existing literature has not yet solved this problem.

First, we collected data on the relative search volume of natural attractions on Google Trends in the United States. Then, we built a panel data model based on the relative search volume (number of visitor arrivals) of 48 natural attractions from 2004 to 2019. Our data includes information on the number of tourist arrivals, ENSO index, economic factors, and socio-demographic factors. In addition, we use the system GMM (SYS-GMM) model to study the impact of ENSO on the number of visitors to natural attractions.

We found that ENSO has a significant negative impact on the number of people arriving at natural attractions. This result suggests that the relevant government management agencies need more innovation in the operation of attractions and entertainment facilities, making tourism companies launch more tourism product portfolios to increase profits. At the same time, it is found that personal disposable income and population can positively adjust the impact of ENSO on the number of visitors to natural attractions, and per capita GDP can negatively adjust the impact of ENSO on the number of visitors to natural attractions.

This research makes several contributions. First of all, the existing literature lacks research on the impact of ENSO on the number of visitors to natural attractions. Therefore, based on quantitative analysis, we considered the same direction of climate change trend on the number of natural attractions. We found that ENSO has a negative impact on the number of visitors to natural attractions. Quantitative evidence expands the scope of literature research in related fields. Second, compared with other associated literature that directly use economic and social demographic factors to affect the number of tourists, we consider the positive adjustment role of personal disposable income and population in this relationship, and per capita GDP is in this relationship. The negative moderating effect 
of this research is to solve the gap in this research. Third, the use of Google Trends (a big data method) to evaluate the number of annual visitors to natural attractions provides new ideas for future research in related fields.

\section{Literature Review}

\subsection{The Impact of ENSO on Natural Tourism}

Climate change is one of the issues of most concern in the world. In the face of the tourism industry's high vulnerability and low resilience, the tourism industry and the overall economy of different countries are far more vulnerable to climate change than their resistance to climate change [12]. In some research literature examining the impact of climate variables on the tourism industry [13-17], the most commonly used climate proxy variables are meteorological variables such as average temperature, rainfall, relative humidity, and wind speed. However, most of these variables are highly correlated [18]. Including two or more meteorological variables in a linear regression model may cause the estimation results to be biased due to multicollinearity. Therefore, it is essential to find a climate index that covers most of the meteorological variables.

The climate phenomenon called the large-scale ocean of climatic shocks-atmospheric circulation will repeatedly cause climate variability. El Nile Southern Oscillation (ENSO) is the world's strongest interannual climate change model and is the subject of research on the effects of climate on agriculture, energy, and health regionally or worldwide [19-22]. However, ENSO is rarely discussed in the field of tourism. Part of the research focuses on the impact of climate cycle patterns on tourism demand and believes that the ENSO impacts tourism demand. For example, Oduber and Ridderstaat found that ENSO significantly affects tourism demand in the United States and the Netherlands [23]. Vivienne and Marra found that during 1994-2011, the climate cycle pattern of the source country was an essential determinant of tourism demand in the Philippines [24]. In recent years, studies have analyzed the Pearson correlation coefficient and linear regression model of ENSO on natural landscapes and found that changes in ENSO will affect the scale of snowfall and wetland ecosystems $[25,26]$.

Moreover, there are also studies on national parks. For example, Lovelock and Feller [27] believe that the increase in ENSO will negatively impact Mangrove Bay in Cape Ridge National Park in Western Australia. Although ENSO is an essential factor affecting tourism, the research literature on this topic is still minimal. as far as we know, the published studies have focused on the formation of natural landscapes, ignoring the research and analysis of the impact of ENSO on the number of visitors to natural attractions. This research is mainly to fill this gap. Based on the above analysis, the following hypothesis is proposed:

Hypothesis 1 (H1). The increase in ENSO will reduce the number of people arriving at natural attractions.

\subsection{The Moderating Effect of Economic Factors (Personal Disposable Income and per Capita GDP)}

Many documents have studied the relationship between tourism activities and economic factors [28-31]. Generally speaking, the development of the tourism industry is related to the macroeconomic environment, the disposable income of tourists, and their leisure time [32]. Economic factors and the length of leisure time are the barriers that restrict tourism activities. On the one hand, with the hypothesis of growth-oriented tourism (GLT) proposed [31], it can be found that gross domestic product (GDP) can drive the development of tourism. On the other hand, transportation, accommodation, and leisure time will play a decisive role in specific tourist activities. Considering that tourism is a symbolic consumption, it is usually given a certain social status [33]. Therefore, compared to disposable income (DI), personal disposable income (DPI) can better analyze tourism needs or the number of tourists arriving. 
It can be seen that at the regional level, the level of economic development and personal disposable income are the key factors for local tourism demand or the number of people arriving. GDP per capita can increase the attractiveness to tourists by increasing recreational facilities in natural scenic spots, thereby adjusting the impact of ENSO on the arrival of natural scenic spots. At the same time, personal disposable income can reduce ENSO's impact on natural scenic spots by breaking the barriers of tourism activities. Therefore, the effect of the number of people arriving, compared with areas with lower per capita GDP and personal disposable income, travel decisions of people with higher per capita GDP and personal disposable income are less affected by ENSO. Based on the above analysis, this article proposes the following hypotheses:

Hypothesis 2 (H2). The level of per capita GDP has a negative regulating effect on the relationship between ENSO and the number of people arriving at natural attractions. When the level of per capita GDP is high, the impact of ENSO on the number of people coming to natural attractions is weakened.

Hypothesis 3 (H3). The level of disposable income negatively affects the relationship between ENSO and the arrival of natural attractions; that is, when the level of disposable income is high, the impact of ENSO on the arrival of natural attractions is weakened.

\subsection{Moderating Effect of Population Size}

In 2005, Faulkner proposed an overall conceptual model of the factors affecting the arrival of tourists to tourist destinations. It was demonstrated that population is an essential factor affecting travel tendency [34]. Therefore, the population size is one of the important foundations for the rapid development of the tourism industry. The larger the population size, the larger the tourism industry's market scale and potential market scale. The research of Eugenio-Martin and Cazorla-Artiles [35] supports this conclusion.

At the regional level, for areas with large populations, population size has a significant role in promoting tourism demand or the number of people arriving. Therefore, the size of the population can adjust the impact of ENSO on the number of people arriving at natural attractions. Compared with areas with relatively small populations, areas with high populations are less affected by external factors like ENSO. Based on the above analysis, the following hypothesis is proposed:

Hypothesis 4 (H4). The population size moderating the relationship between ENSO and the number of people arriving at natural attractions; the larger the population size, the more negative the relationship between ENSO and the number of people arriving at natural attractions will be weakened.

\section{Methods}

\subsection{Data and Variables}

\subsubsection{Dependent Variable: The Number of Tourists}

In the Internet age, search engines have become our main travel tool. The data collected can break the barriers of traditional data collection methods and meet the requirements of data scope, accuracy, flexibility, and update speed. Taking Swiss tourism, U.S. national parks, and Babacas as examples, it was discovered that Google Trends data could be highly accurate as of the myopia value of tourist arrivals. [36,37]. On this basis, we use Google Trends data as a proxy variable for annual visitor arrivals. Google Trends data normalizes absolute search volume to relative search volume in the range of 0-100 in a certain "normalized" way. However, the relative search volume data of Google Trends does not affect the validity of the research conclusions, which will be explained in the "robustness" section below.

We use the annual traffic of 48 natural attractions in the United States from 2004 to 2019 from the official website of Google Trends. Considering the representativeness and 
completeness of the data, we choose the travel data of the United States as the explained variable. Considering that some natural attractions have a small number of visitors, the relative search volume is 0 after the "standardization" operation of Google trend data, which will interfere with the estimation results of the model. Therefore, we discarded these attractions when selecting samples. To fit the model requirements, we convert monthly data to annual data. In addition, a logarithmic transformation of the Google trend data is performed to reduce the possible impact of heteroscedasticity.

\subsubsection{Independent Variable: ENSO Index}

The climate index is a characterization of climate phenomena. Researchers have developed, improved, and used many indexes to study the natural oscillation phenomenon related to El Nilo. For example, the Southern Oscillation Index (SOI), Niño3, Niño4, Niño3.4 and Niño1.2, etc. For example, the Niño1.2 area (0N-10S, 90W-80W) corresponds to the coastal regions of South America and the coast of Ecuador. It affects the sea surface temperature (SST), which affects the global sea surface temperature [38].

Although the sea area of Niño1.2 area is relatively small, the annual and interannual changes in sea surface temperature are apparent. Some studies have shown that the Niño1.2 index has an excellent characterizing role in measuring the periodic fluctuations of precipitation [38]. Therefore, this study uses the Niño1.2 index as a proxy variable for climate change. The data comes from the monthly data of the National Oceanic and Atmospheric Administration (NOAA) Niño1.2 index. Taking into account the model requirements, the monthly data is converted into annual data for fitting.

\subsubsection{Control Variables}

Since the search areas corresponding to the keywords on the Google Trends website are derived from the states where the natural attractions are located, this study uses each state's GDP, personal disposable income, and population data-considering the economic variables GDP, DPI, and population as control variables, using the DPI data of the US states from 2004 to 2019 released by the Bureau of Economic Analysis (BEA), corresponding to the selected 48 states of natural attractions. The variable description, correlation matrix, and descriptive statistics of each variable are shown in Tables 1-3, respectively.

Table 1. Variable description.

\begin{tabular}{|c|c|}
\hline Variable & Describe \\
\hline $\operatorname{LnALL}_{i, \mathrm{t}}$ & In year $\mathrm{t}$, the logarithm of the number of people searched for natural attraction i on Google Trends \\
\hline NINO12 ${ }_{i, t}$ & In year $t$, the proxy variable of climate index of natural scenic spot $i$ \\
\hline $\operatorname{lnDPI} I_{i, t}$ & In year $t$, the personal disposable income of the state where natural attraction $i$ is located \\
\hline $\operatorname{lnGDP}{ }_{i . t}$ & In year $t$, the GDP of the state where the natural attraction $i$ is located \\
\hline $\operatorname{lnpopulation}_{\mathrm{i}, \mathrm{t}}$ & In year $t$, the population of the state where the natural attraction $i$ is located \\
\hline
\end{tabular}

Table 2. Correlation analysis of variables.

\begin{tabular}{cccccc}
\hline Variables & $\ln$ ALL & NINO12 & $\operatorname{lnDPI}$ & lnpopulation & $\operatorname{lnGDP}$ \\
\hline lnALL & 1.000 & & & & \\
NINA12 & $0.105^{* * *}$ & 1.000 & & & \\
lnDPI & $-0.245^{* * *}$ & 0.042 & 1.000 & & \\
lnpopulation & $-0.292^{* * *}$ & 0.011 & $0.991^{* * *}$ & 1.000 & 1.000 \\
lnGDP & $-0.273^{* * *}$ & 0.016 & $0.995^{* * *}$ & $0.992^{* * *}$ & \\
*** $^{*<0.01, * *} p<0.05^{*} p<0.1$. & & &
\end{tabular}


Table 3. Descriptive statistical analysis of variables.

\begin{tabular}{cccccc}
\hline Variables & N & Mean & S.D. & Min & Max \\
\hline ALL & 768 & 1761 & 884.4 & 100 & 4122 \\
NINO12 & 768 & -0.0841 & 0.556 & -1.067 & 1.433 \\
GDP & 768 & 801,946 & 941,142 & 31,567 & $2,800,505.4$ \\
DPI & 768 & 588,827 & 694,220 & 16,262 & $2,267,563.9$ \\
population & 768 & $14,113,752.6$ & $15,270,379.6$ & 509,106 & $39,437,610$ \\
\hline
\end{tabular}

\subsection{Empirical Analysis Results}

\subsubsection{Empirical Econometric Model}

We construct the following measurement model based on the variables above:

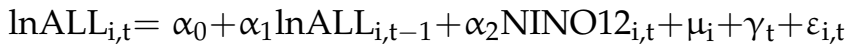

where $\ln A L L_{i, t}$ is the dependent variable, the number of visitors to the scenic spot $i$ in year $\mathrm{t}$; NINO12 $2_{i, t}$ is the explanatory variable, the climate index of scenic spot $\mathrm{i}$ in year $\mathrm{t} ; \alpha_{0}$ is a constant; $\alpha_{1}, \alpha_{2}$ are parameters; $\mu_{\mathrm{i}}$ is an unobservable individual fixed effect; $\gamma_{\mathrm{t}}$ is a time fixed effect; $\varepsilon_{i, t}$ is an error term.

Considering the adjustment effect of personal disposable income level, gross domestic product, and population size on ENSO and tourist arrivals, the interaction terms of NINO12 index and DPI, NINO12 index, and GDP, NINO12 index, and population are introduced. Furthermore, considering that the magnitude of DPI, GDP, and the population is much larger than the magnitude of the NINO12 index and lnALL, we perform logarithmic conversion of DPI, GDP, and population. As a result, the interaction terms of NINO12 index and DPI, NINO12 index and GDP, NINO12, and population are represented by $\mathrm{NINO}_{2} \mathrm{t} \times \ln \left(\mathrm{DPI}_{\mathrm{i}, \mathrm{t}}\right), \mathrm{NINO}_{2} \mathrm{t} \times \ln \left(\mathrm{GDP}_{\mathrm{i}, \mathrm{t}}\right)$ and $\mathrm{NINO}_{2} \mathrm{t} \times \ln \left(\right.$ population $\left._{\mathrm{i}, \mathrm{t}}\right)$, then the model (2)-(4) can be obtained:

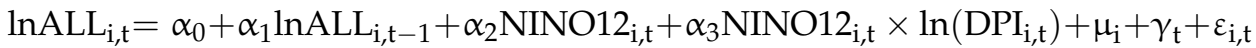

$$
\begin{aligned}
& \ln A L L_{i, t}=\alpha_{0}+\alpha_{1} \ln A L L_{i, t-1}+\alpha_{2} \text { NINO12 }_{i, t}+\alpha_{4} \text { NINO12 }_{i, t} \times \ln \left(\mathrm{GDP}_{i, t}\right)+\mu_{i}+\gamma_{t}+\varepsilon_{i, t}
\end{aligned}
$$

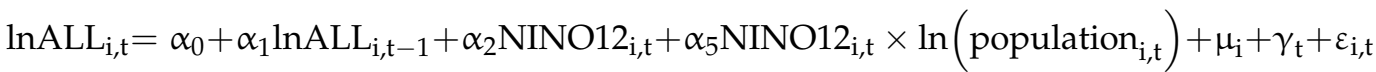

Among them, $\ln \left(\mathrm{DPI}_{\mathrm{i}, \mathrm{t}}\right), \ln \left(\mathrm{GDP}_{\mathrm{i}, \mathrm{t}}\right)$ and $\ln \left(\right.$ population $\left._{\mathrm{i}, \mathrm{t}}\right)$ are control variables, which respectively represent the personal disposable income, GDP, and population of the state where scenic spot $\mathrm{i}$ is located in year $\mathrm{t} ; \alpha_{3}, \alpha_{4}, \alpha_{5}$ are parameters; $\ln \left(\mathrm{ALL}_{\mathrm{i}, \mathrm{t}}\right), \mathrm{NINO} 2_{\mathrm{i}, \mathrm{t}}, \alpha_{0}$, $\alpha_{1}, \alpha_{2}, \mu_{i}, \gamma_{t}, \varepsilon_{i, t}$ have the same meaning as in model (1).

Considering that the dependent variable is the number of tourist arrivals, it is expected that this variable will change over time. In the tourism-related literature, this change is considered a seasonal pattern [39]. For example, some regions have pleasant weather in spring and autumn, and most people with outdoor tourism needs will choose to travel in these two seasons. Therefore, the number of natural tourist attractions in the spring and autumn seasons is higher than in the other two seasons. To control this fixed time effect, a set of time dummy variables are added to model (2)-(4), and the model (5)-(7) is obtained as follows:

$$
\begin{aligned}
& \ln \mathrm{ALL}_{\mathrm{i}, \mathrm{t}}=\alpha_{0}+\alpha_{1} \ln \mathrm{ALL}_{\mathrm{i}, \mathrm{t}-1}+\alpha_{2} \mathrm{NINO} 12_{\mathrm{i}, \mathrm{t}}+\alpha_{3} \mathrm{NINO}_{2} 2_{\mathrm{i}, \mathrm{t}} \times \ln \left(\mathrm{DPI}_{\mathrm{i}, \mathrm{t}}\right)+\eta \mathrm{P}_{\mathrm{i}, \mathrm{n}}+\mu_{\mathrm{i}}+\gamma_{\mathrm{t}}+\varepsilon_{\mathrm{i}, \mathrm{t}}
\end{aligned}
$$

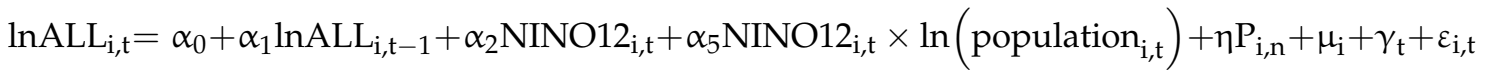

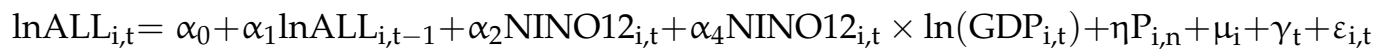

Among them, $P$ is a time dummy variable; $n$ time periods $(=1,2,3,4), \eta$ is a parameter; $\ln \left(\mathrm{ALL}_{\mathrm{i}, \mathrm{t}}\right), \mathrm{NINO} 12_{\mathrm{i}, \mathrm{t}}, \alpha_{0}, \alpha_{1}, \alpha_{2}, \alpha_{3}, \alpha_{4}, \alpha_{5}, \mu_{\mathrm{i}}, \gamma_{\mathrm{t}}$ have the same meaning as in the models (1)-(4). 


\subsubsection{Endogeneity}

In this study, due to the tourism industry's extensive economic growth mode and intensive economic growth mode, there may be path dependence effects [40]. The path dependence formed by the scale of tourist arrivals at tourist attractions may also enable relevant management or operating institutions to strengthen system-driven management, optimize the allocation of resource elements, and transform and upgrade to "innovation-driven" to achieve sustainable development goals, thereby increasing employment opportunities and raise the level of personal disposable income and GDP. This shows that the level of personal disposable income, gross domestic product, and the number of tourists have an endogenous problem of mutual causality. At the same time, the existence of missing variables will also produce endogeneity. For example, the ticket price of scenic spots is a key issue in tourism research [41]. The increase (decrease) of ticket prices may become a key factor for tourists to choose attractions, making the number of tourists at a certain attraction decrease (increase). If this is the case, the regression estimation coefficients obtained by the general linear regression model may be biased [42].

Considering the above problems, we use the dynamic paneled system GMM (SYSGMM) model for estimation. Using ENSO and the first-order lag of the arrival of the number of people as instrumental variables can effectively solve the endogeneity problems caused by reverse causality and missing variables [43-45]. At the same time, considering that in the case of a small sample, the two-step SYS-GMM of the SYS-GMM model can significantly reduce the estimation bias, so this study chooses the two-step SYS-GMM model to determine the relationship between ENSO and the number of tourists to perform quantitative analysis.

\section{Results and Discussion}

Due to space limitations, this article does not report the estimation results of models (1)-(4), and the estimation results of models (5)-(7) are shown in Table 4. The AR(1) and AR(2) values of the residual series correlation test in Table 4 show that the error terms of the SYS-GMM model all have first-order autocorrelation, but there is no second-order autocorrelation, which proves that in both GMM models there is no problem of over-identification of instrumental variables.

\subsection{Does ENSO Affect the Number of Visitors to Natural Attractions?}

The models (5)-(7) in Table 4 all show that the lagging period between the core explanatory variable and the explained variable is significantly negative at a confidence level of $1 \%$, indicating that the enhancement of ENSO in the current period will shrink in the next year. Thus, the number of natural attractions in the United States has reached scale, supporting Hypothesis 1 . In addition, on the one hand, this is related to the changes and frequency of ENSO on temperature, rainfall, extreme weather, etc., over a long period. On the other hand, from the perspective of the natural landscape environment, the increase of ENSO may increase public facilities and ecological landscape. The destruction is thereby reducing tourists' motivation to visit and reducing the number of tourists arriving.

\subsection{Does per Capita Disposable Income Have a Moderating Effect on the Relationship between ENSO and the Number of Visitors to Natural Attractions?}

Model (5) in Table 4, to test the adjustment effect of personal disposable income (DPI), considers the crossover term of ENSO index, NINO12 and personal disposable income $\left(\mathrm{NINO}_{2} \mathrm{t}_{\mathrm{t}} \times \operatorname{lnDPI} \mathrm{i}_{\mathrm{i}, \mathrm{t}}\right)$. The results show that the crossover term coefficient is positive and is significant at the level of $5 \%$ confidence, indicating that the higher the personal disposable income, the negative impact of ENSO on the arrival of natural attractions can be effectively suppressed, supporting Hypothesis 2 . People with relatively high disposable income can pay for transportation, accommodation, shopping, and other expenses incurred in tourism activities and make travel decisions more quickly. Compared with people with 
low personal disposable income, their willingness to travel is greater and so strong that it reduces the negative impact brought by ENSO enhancement to a certain extent.

Table 4. Estimation results of the impact of ENSO on the number of visitors to natural attractions.

\begin{tabular}{|c|c|c|c|}
\hline \multirow{2}{*}{ Variable } & \multicolumn{3}{|c|}{ SYS-GMM } \\
\hline & (5) & (6) & (7) \\
\hline $\ln A L L_{i, t-1}$ & $\begin{array}{c}0.3250 * * * \\
(0.0867)\end{array}$ & $\begin{array}{c}0.3240 * * * \\
(0.0862)\end{array}$ & $\begin{array}{c}0.3260^{* * *} \\
(0.0863)\end{array}$ \\
\hline $\mathrm{NINO}_{12}$ & $\begin{array}{c}-0.5750 * * \\
(0.2350)\end{array}$ & $\begin{array}{c}-0.7620 * * * \\
(0.2930)\end{array}$ & $\begin{array}{c}-0.5700^{* *} \\
(0.2440)\end{array}$ \\
\hline $\mathrm{NINO}_{12} \times \operatorname{lnDPI}_{\mathrm{i}, \mathrm{t}}$ & $\begin{array}{c}0.0439 * * \\
(0.0192)\end{array}$ & & \\
\hline NINO12 $_{t} \times \operatorname{lnpopulation}_{\mathrm{i}, \mathrm{t}}$ & & $\begin{array}{c}0.0468 \text { ** } \\
(0.0190)\end{array}$ & \\
\hline $\mathrm{NINO}_{12} \times \operatorname{lnGDP}{ }_{\mathrm{i}, \mathrm{t}}$ & & & $\begin{array}{l}0.0426^{* *} \\
(0.0196)\end{array}$ \\
\hline Constant & $\begin{array}{l}4.762^{* * *} \\
(0.5960)\end{array}$ & $\begin{array}{l}4.782 * * * \\
(0.5930)\end{array}$ & $\begin{array}{c}4.766^{* * *} \\
(0.595)\end{array}$ \\
\hline Observations & 720 & 720 & 720 \\
\hline Time fixed effect & YES & YES & YES \\
\hline No. of firms & 48 & 48 & 48 \\
\hline No. of instr. variables & 31 & 31 & 31 \\
\hline Wald stat. & $49,875.6000$ & $50,128.8000$ & $50,317.8000$ \\
\hline Hansen test & 0.0663 & 0.0721 & 0.0712 \\
\hline $\mathrm{AR}(1)$ & 0.0000 & 0.0000 & 0.0000 \\
\hline $\operatorname{AR}(2)$ & 0.2030 & 0.2030 & 0.2020 \\
\hline
\end{tabular}

\subsection{Does the Population Size Have a Moderating Effect on the Relationship between ENSO and the Number of Visitors to Natural Attractions?}

The model (6) in Table 4 introduces the crossover term $\left(\right.$ NINO12 $\left._{t} \times \operatorname{lnpopulation}_{\mathrm{i}, \mathrm{t}}\right)$ between the ENSO index, NINO12 and the size of the population (population). The results show that the regression coefficient of the crossover term NINO12 $\mathrm{t} \times \ln _{\mathrm{n} \text { population }} \mathrm{i}_{\mathrm{i}, \mathrm{t}}$ is significantly positive at the $5 \%$ level, indicating that the crossover term The introduction of ENSO weakened the influence of ENSO on the arrival of natural attractions, that is, the increase in population size can weaken the negative impact of ENSO on the arrival of natural attractions, supporting Hypothesis 3 . On the one hand, the larger the population size, the larger the market scale of the tourism industry; on the other hand, this paper studies the influence of the local population size on the number of people arriving at local natural attractions, and ENSO changes weather conditions by affecting temperature and rainfall. As a result, the local weather conditions can be observed in real-time, so their travel activities are more flexible, which alleviates the negative impact of ENSO on the number of natural attractions.

4.4. Does per Capita GDP Have a Moderating Effect on the Relationship between ENSO and the Number of Visitors to Natural Attractions?

The model (7) in Table 4 considers the cross-product (NINO12 $\left.\mathrm{t} \times \operatorname{lnGDP} \mathrm{i}_{\mathrm{i}, \mathrm{t}}\right)$ between the ENSO index, NINO12 and per capita gross domestic product (GDP). The results show that the cross-product NINO12 $\mathrm{t} \times \operatorname{lnGDP}_{\mathrm{i}, \mathrm{t}}$ is significantly positive at the $5 \%$ level, indicating that the increase in per capita GDP can weaken the negative impact of ENSO on ENSO the number of natural attractions. This supports Hypothesis 4. The higher the per capita GDP, the higher the economic development level of the corresponding region, the more convenient the urban transportation, the more efficient reception of tourism information, and the higher the level of regional economic development, the higher the level of regional economic growth, the operation, and maintenance of the corresponding 
natural attractions by the relevant management and management agencies. More capital investment increases the attractiveness of scenic spots' ecological environment and recreational facilities. It slows down ENSO's increased damage to ecological landscapes. Therefore, a higher per capita GDP suppresses the negative impact of ENSO on the number of visitors to natural attractions.

The above results are consistent with the conclusions of most research literature on the impact of climate change on natural tourism, such as Liu [46]. The difference is that this study considers the adjustment effect of economic and social demographic factors based on the core explanatory variable NINO12 index.

\subsection{Robustness Check}

To ensure the reliability of the research conclusions, this research will conduct robustness checks considering the following two aspects. On one hand, the independent variable and the lagging first-order of the moderating effect term are considered for re-measurement. On the other hand, we narrowed the sample range which from 2004 to 2015.

Columns (1)-(3) of Table 5 report the estimation results considering the lag effect. It can be seen that the signs and significance of the coefficients of the lag phase ENSO index and the interaction terms NINO12 $2_{t} \times \operatorname{lnDPI}_{i, t}, \mathrm{NINO}_{2} 2_{\mathrm{t}} \times \operatorname{lnpopulation}_{\mathrm{i}, \mathrm{t}}$, and $\mathrm{NINO}_{2} \mathrm{t} \times \operatorname{lnGDP}_{\mathrm{i}, \mathrm{t}}$ are consistent with the benchmark regression estimation results in Table 4. This shows that the conclusions of this study are robust.

Table 5. Robustness regression estimation results.

\begin{tabular}{|c|c|c|c|c|c|c|}
\hline \multirow[b]{2}{*}{ Variable } & \multicolumn{3}{|c|}{ Consider the Lag Term } & \multicolumn{3}{|c|}{ Shorten the Sample Period } \\
\hline & $\begin{array}{l}(1) \\
\text { DPI }\end{array}$ & $\begin{array}{c}(2) \\
\text { Inpopulation }\end{array}$ & $\begin{array}{l}\text { (3) } \\
\text { DPI }\end{array}$ & $\begin{array}{l}\text { (4) } \\
\text { DPI }\end{array}$ & $\begin{array}{c}\text { (5) } \\
\text { lnpopulation }\end{array}$ & $\begin{array}{l}\text { (6) } \\
\text { DPI }\end{array}$ \\
\hline $\ln \mathrm{ALL}_{\mathrm{i}, \mathrm{t}-1}$ & $\begin{array}{c}0.3010^{* * *} \\
(0.0795)\end{array}$ & $\begin{array}{c}0.2880^{* * *} \\
(0.0788)\end{array}$ & $\begin{array}{c}0.2900^{* * *} \\
(0.0771)\end{array}$ & $\begin{array}{c}0.3490 * * * \\
(0.1300)\end{array}$ & $\begin{array}{c}0.3470^{* * *} \\
(0.1300)\end{array}$ & $\begin{array}{c}0.3480^{* * *} \\
(0.1310)\end{array}$ \\
\hline $\mathrm{NINO} 12_{\mathrm{t}}$ & & & & $\begin{array}{c}-0.6210^{* *} \\
(0.2450)\end{array}$ & $\begin{array}{l}-0.8220^{* * *} \\
(0.3120)\end{array}$ & $\begin{array}{l}-0.6130 * * \\
(0.2570)\end{array}$ \\
\hline $\mathrm{NINO}_{2} \mathrm{t} \times \operatorname{lnDPI} \mathrm{i}_{\mathrm{i}, \mathrm{t}}$ & & & & $\begin{array}{l}0.0478^{* *} \\
(0.0201)\end{array}$ & & \\
\hline NINO12 $_{t} \times$ lnpopulation $_{i, t}$ & & & & & $\begin{array}{c}0.0507 * * \\
(0.0202)\end{array}$ & \\
\hline $\mathrm{NINO}_{2} \mathrm{t} \times \operatorname{lnGDP} \mathrm{i}_{\mathrm{i}, \mathrm{t}}$ & & & & & & $\begin{array}{l}0.0460 * * \\
(0.0206)\end{array}$ \\
\hline $\mathrm{NINO} 12_{\mathrm{t}-1}$ & $\begin{array}{c}-1.1780 * * \\
(0.5300)\end{array}$ & $\begin{array}{l}-2.0210 * * \\
(0.8120)\end{array}$ & $\begin{array}{l}-1.5710 * * \\
(0.6260)\end{array}$ & & & \\
\hline $\mathrm{NINO}_{2} \mathrm{t}_{-1} \times \mathrm{L} \cdot \operatorname{lnDPIi}, \mathrm{t}-1$ & $\begin{array}{l}0.0949 * * \\
(0.0433)\end{array}$ & & & & & \\
\hline $\mathrm{NINO}_{12} \mathrm{t}-1 \times$ L.lnpopulationi, $\mathrm{t}-1$ & & $\begin{array}{l}0.1290 * * \\
(0.0521)\end{array}$ & & & & \\
\hline $\mathrm{NINO}{ }_{\mathrm{t}-1} \times \mathrm{L} . \operatorname{lnGDPi}, \mathrm{t}-1$ & & & $\begin{array}{l}0.1240 * * \\
(0.0499)\end{array}$ & & & \\
\hline Constant & $\begin{array}{l}4.9580^{* * *} \\
(0.5620)\end{array}$ & $\begin{array}{c}5.0590 * * * \\
(0.5590)\end{array}$ & $\begin{array}{l}5.0450 * * * \\
(0.5480)\end{array}$ & $\begin{array}{l}4.6050 * * * \\
(0.8740)\end{array}$ & $\begin{array}{l}4.6290 * * * \\
(0.8740)\end{array}$ & $\begin{array}{l}4.6200 * * * \\
(0.8860)\end{array}$ \\
\hline Observations & 720 & 720 & 720 & 528 & 528 & 528 \\
\hline Time fixed effect & YES & YES & YES & YES & YES & YES \\
\hline No. of firms & 48 & 48 & 48 & 48 & 48 & 48 \\
\hline No. of instr. variables & 31 & 31 & 31 & 23 & 23 & 23 \\
\hline Wald stat. & $32,904.2000$ & $30,459.3000$ & $30,307.9000$ & $43,451.9000$ & $43,516.0000$ & $44,078.2000$ \\
\hline Hansen test & 0.0718 & 0.0782 & 0.0839 & 0.0704 & 0.0708 & 0.0726 \\
\hline $\mathrm{AR}(1)$ & 0.0000 & 0.0000 & 0.0000 & 0.0000 & 0.0000 & 0.0000 \\
\hline $\operatorname{AR}(2)$ & 0.4300 & 0.7450 & 0.7170 & 0.1420 & 0.1430 & 0.1440 \\
\hline
\end{tabular}

Standard errors in parentheses ${ }^{*} p<0.1,{ }^{* *} p<0.05,{ }^{* * *} p<0.01$, where NINO12 $\mathrm{t} \times \operatorname{lnDPI} \mathrm{i}_{\mathrm{t}, \mathrm{t}}, \mathrm{NINO}_{2} \mathrm{t} \times \operatorname{lnpopulation} \mathrm{i}_{\mathrm{t}, \mathrm{t}}, \mathrm{NINO}_{2} 2_{\mathrm{t}} \times \operatorname{lnGDP}_{\mathrm{i}, \mathrm{t}}$ means interactive item. 
Columns (4)-(6) of Table 5 show the parameter estimation results for the adjusted sample period from 2004 to 2015. After re-regression using the SYS-GMM model, the conclusions are drawn are the same as the conclusions in Table 4, which further improves the reliability of the conclusions.

\section{Conclusions}

This research establishes a mechanism that considers the adjustment effect of personal disposable income, population size, and per capita GDP to analyze the impact of ENSO on the arrival of natural attractions, providing a new perspective for ENSO and tourism research. The empirical research conducted on 48 natural attractions in the United States not only verified that ENSO has a negative impact on tourist arrivals but also found that different personal disposable incomes, population sizes, and per capita GDP have negative moderating effects on ENSO's impact on the number of tourist arrivals. In this empirical study, the use of Google Trend data is a use of big data methods. More advanced research provides a solid foundation. This research offers new insights for relevant natural attractions management agencies or tourism companies to cope with climate change and enable the sustainable development of natural attractions.

The research presented in this paper has some limitations which can be resolved in future research. First, this study discusses the moderating effects of personal disposable income, population, and per capita GDP in the impact of ENSO on tourism but lacks a discussion of qualitative variables, for example, education level, culture, environment, etc. Future research must introduce more control variables to reveal the impact of ENSO more comprehensively. Second, since ENSO is a long-term accumulation process, this study uses annual data for empirical analysis. Third, weekends and holidays have the same impact every year. Future research can introduce weekends and holidays on a monthly or quarterly level to explore the effects of ENSO to enrich the level of research on the impact of ENSO on natural tourist attractions.

Author Contributions: Conceptualization, L.X., K.G. and W.X.; Data curation, Q.T.; Investigation, Y.D.; Methodology, L.X., K.G., Q.T. and Y.D.; Project administration, K.G. and W.X.; Software, L.X., Q.T. and Y.D.; Supervision, K.G. and W.X.; Writing-original draft, L.X.; Writing-review \& editing, L.X., K.G., Q.T., Y.D. and W.X. All authors have read and agreed to the published version of the manuscript.

Funding: This article was supported by the National Natural Science Foundation of China (Grant Nos. 71871034, 71701116, and 71801113).

Institutional Review Board Statement: Not applicable.

Informed Consent Statement: Not applicable.

Data Availability Statement: The data supporting the reported results are available from the corresponding author on reasonable request.

Conflicts of Interest: The authors declare no conflict of interest.

\section{References}

1. Becken, S.; Hay, J.E. Climate Change and Tourism: From Policy to Practice; Routledge: Oxfordshire, UK, 2012 ; pp. 1-280.

2. Becken, S.; Wilson, J. The impacts of weather on tourist travel. Tour. Geogr. 2013, 15, 620-639. [CrossRef]

3. Xie, X.; Zhou, S.; Zhang, J.; Huang, P. The role of background SST changes in the ENSO-driven rainfall variability revealed from the atmospheric model experiments in CMIP5/6. Atmos. Res. 2021, 261, 105732. [CrossRef]

4. Singh, S.; Srivastava, P.; Abebe, A.; Mitra, S. Baseflow response to climate variability induced droughts in the ApalachicolaChattahoochee-Flint River Basin, U.S.A. J. Hydrol. 2015, 528, 550-561. [CrossRef]

5. McCullum, A.J.; Gurdak, J. Groundwater level response in U.S. principal aquifers to ENSO, NAO, PDO, and AMO. J. Hydrol. 2014, 519, 1939-1952.

6. Karnauskas, K.B.; Donnelly, J.P.; Barkley, H.C.; Martin, J.E. Coupling between air travel and climate. Nat. Clim. Chang. 2015, 5, 1068-1073. [CrossRef]

7. Mortlock, T.R.; Goodwin, I. Impacts of enhanced central Pacific ENSO on wave climate and headland-bay beach morphology. Cont. Shelf Res. 2016, 120, 14-25. [CrossRef] 
8. Masters, P.M. Holocene sand beaches of southern California: ENSO forcing and coastal processes on millennial scales. Palaeogeogr. Palaeoclim. Palaeoecol. 2006, 232, 73-95. [CrossRef]

9. Kronenberg, K.; Fuchs, M. Aligning tourism's socio-economic impact with the United Nations' sustainable development goals. Tour. Manag. Perspect. 2021, 39, 100831. [CrossRef]

10. Song, H.; Dwyer, L.; Li, G.; Cao, Z. Tourism economics research: A review and assessment. Ann. Tour. Res. 2012, 39, 1653-1682. [CrossRef]

11. Li, T.; Li, Q.; Liu, J. The spatial mobility of rural tourism workforce: A case study from the micro analytical perspective. Habitat Int. 2021, 110, 102322. [CrossRef]

12. Dogru, T.; Marchio, E.A.; Bulut, U.; Suess, C. Climate change: Vulnerability and resilience of tourism and the entire economy. Tour. Manag. 2019, 72, 292-305. [CrossRef]

13. Morin, S.; Samacoïts, R.; François, H.; Carmagnola, C.M.; Abegg, B.; Demiroglu, O.C.; Pons, M.; Soubeyroux, J.-M.; Lafaysse, M.; Franklin, S.; et al. Pan-European meteorological and snow indicators of climate change impact on ski tourism. Clim. Serv. 2021, 22, 100215. [CrossRef]

14. Agnew, M.D.; Palutikof, J. Impacts of short-term climate variability in the UK on demand for domestic and international tourism. Clim. Res. 2006, 31, 109-120. [CrossRef]

15. Maddison, D. In Search of Warmer Climates? The Impact of Climate Change on Flows of British Tourists. Clim. Chang. 2001, 49, 193-208. [CrossRef]

16. Kim, T.; Shin, J.-Y.; Kim, S.; Heo, J.-H. Identification of relationships between climate indices and long-term precipitation in South Korea using ensemble empirical mode decomposition. J. Hydrol. 2018, 557, 726-739. [CrossRef]

17. Dube, K.; Nhamo, G. Climate variability, change and potential impacts on tourism: Evidence from the Zambian side of the Victoria Falls. Environ. Sci. Policy 2018, 84, 113-123. [CrossRef]

18. Yuan, J.; Wu, Y.; Jing, W.; Liu, J.; Du, M.; Wang, Y.; Liu, M. Association between meteorological factors and daily new cases of COVID-19 in 188 countries: A time series analysis. Sci. Total Environ. 2021, 780, 146538. [CrossRef]

19. de la Casa, A.; Ovando, G.; Díaz, G. Linking data of ENSO, NDVI-MODIS and crops yield as a base of an early warning system for agriculture in Córdoba, Argentina. Remote Sens. Appl. Soc. Environ. 2021, 22, 100480. [CrossRef]

20. An-Vo, D.-A.; Mushtaq, S.; Reardon-Smith, K.; Kouadio, L.; Attard, S.; Cobon, D.; Stone, R. Value of seasonal forecasting for sugarcane farm irrigation planning. Eur. J. Agron. 2019, 104, 37-48. [CrossRef]

21. Henao, F.; Viteri, J.P.; Rodríguez, Y.; Gómez, J.; Dyner, I. Annual and interannual complementarities of renewable energy sources in Colombia. Renew. Sustain. Energy Rev. 2020, 134, 110318. [CrossRef]

22. Anyamba, A.; Chretien, J.-P.; Small, J.; Tucker, C.J.; Linthicum, K.J. Developing global climate anomalies suggest potential disease risks for 2006-2007. Int. J. Health Geogr. 2006, 5, 60. [CrossRef] [PubMed]

23. Oduber, M.; Ridderstaat, J. Impacts of Cyclic Patterns of Climate on Fluctuations in Tourism Demand: Evidence from Aruba. J. Tour. Res. Hosp. 2017, 6, 1-10. [CrossRef]

24. Ewis, E.-S. Exploring Changes in the Agricultural Calendar as a Response to Climate Variability in Egypt. In Climate Change Impacts on Agriculture and Food Security in Egypt; Springer Water: Cham, Switzerland, 2020; pp. 249-271. [CrossRef]

25. Meng, L.; Ma, Y. On the relationship of lake-effect snowfall and teleconnections in the Lower Peninsula of Michigan, USA. J. Great Lakes Res. 2021, 47, 134-144. [CrossRef]

26. Ilyas, S.; Xu, X.; Jia, G.; Zhang, A. Interannual Variability of Global Wetlands in Response to El Niño Southern Oscillations (ENSO) and Land-Use. Front. Earth Sci. 2019, 7, 289. [CrossRef]

27. Lovelock, C.E.; Feller, I.C.; Reef, R.; Hickey, S.; Ball, M. Mangrove dieback during fluctuating sea levels. Sci. Rep. 2017, 7, 1-8. [CrossRef] [PubMed]

28. Kadir, N.; Nayan, S.; Abdullah, M. The Causal Relationship Between Tourism and Economic Growth in Malaysia: Evidence from Multivariate Causality Tests. Encontros Cient.-Tour. Manag. Stud. 2010, 6, 16-24.

29. Snieska, V.; Barkauskienè, K.; Barkauskas, V. The Impact of Economic Factors on the Development of Rural Tourism: Lithuanian Case. Procedia-Soc. Behav. Sci. 2014, 156, 280-285. [CrossRef]

30. Scarlett, H.G. Tourism recovery and the economic impact: A panel assessment. Res. Glob. 2021, 3, 100044. [CrossRef]

31. del P. Pablo-Romero, M.; Molina, J.A. Tourism and economic growth: A review of empirical literature. Tour. Manag. Perspect. 2013, 8, 28-41. [CrossRef]

32. Todd, S. Self-concept: A tourism application. J. Consum. Behav. 2001, 1, 184-196. [CrossRef]

33. Ma, M.; Hassink, R. An evolutionary perspective on tourism area development. Ann. Tour. Res. 2013, 41, 89-109. [CrossRef]

34. Faulkner, B.H.W. Developing strategic approaches to tourism destination marketing: The Australian experience. In Global Tourism, 3rd ed.; Routledge: London, UK, 2005; pp. 326-345. [CrossRef]

35. Eugenio-Martin, J.L.; Cazorla-Artiles, J.M. The shares method for revealing latent tourism demand. Ann. Tour. Res. 2020, 84, 102969. [CrossRef]

36. Feng, Y.; Li, G.; Sun, X.; Li, J. Forecasting the number of inbound tourists with Google Trends. Procedia Comput. Sci. 2019, 162, 628-633. [CrossRef]

37. Dergiades, T.; Mavragani, E.; Pan, B. Google Trends and tourists' arrivals: Emerging biases and proposed corrections. Tour. Manag. 2018, 66, 108-120. [CrossRef] 
38. Siliverstovs, B.; Wochner, D.S. Google Trends and reality: Do the proportions match?: Appraising the informational value of online search behavior: Evidence from Swiss tourism regions. J. Econ. Behav. Organ. 2018, 145, 1-23. [CrossRef]

39. Bokelmann, B.; Lessmann, S. Spurious patterns in Google Trends data-An analysis of the effects on tourism demand forecasting in Germany. Tour. Manag. 2019, 75, 1-12. [CrossRef]

40. Dimanche, F.; Samdahl, D. Leisure as symbolic consumption: A concep-tualization and prospectus for future research. Leis. Sci. 1994, 16, e119-e129. [CrossRef]

41. Bilen, M.; Yilanci, V.; Eryüzlü, H. Tourism development and economic growth: A panel Granger causality analysis in the frequency domain. Curr. Issues Tour. 2015, 20, 27-32. [CrossRef]

42. Wang, T.; Wu, P.; Ge, Q.; Ning, Z. Ticket prices and revenue levels of tourist attractions in China: Spatial differentiation between prefectural units. Tour. Manag. 2021, 83, 104214. [CrossRef]

43. Goh, C.; Law, R. Modeling and forecasting tourism demand for arrivals with stochastic nonstationary seasonality and intervention. Tour. Manag. 2002, 23, 499-510. [CrossRef]

44. Hwang, R.L.; Lin, T.P.; Matzarakis, A. Seasonal effect of urban street shading on long-term outdoor thermal comfort. Build. Environ. 2011, 46, 863-870. [CrossRef]

45. Lim, C.; McAleer, M. Monthly seasonal variations: Asian tourism to Australia. Ann. Tour. Res. 2001, 28, 68-82. [CrossRef]

46. Blundell, R.; Bond, S. Initial conditions and moment restrictions in dynamic panel data models. J. Econ. 1998, 87, 115-143. [CrossRef] 